\title{
ANALISIS HUKUM STATUS KEWARGANEGARAAN GANDA MENURUT UNDANG-UNDANG NOMOR 12 TAHUN 2006 TENTANG KEWARGANEGARAAN
}

\author{
Oleh
}

Muliadi

Fakultas Hukum Universitas Muhammadiyah Palu

muliadi.rusmana@gmail.com

\begin{abstract}
Abstrak
Warga negara merupakan salah satu unsur dari negara yang harus dipenuhi untuk bisa disebut sebagai sebuah Negara, Indonesia secara tegas tidak menerapkan status kewarganegaraan ganda di dalam Undang-Undang Nomor 12 tahun 2006 tentang Kewarganegaraan, kecuali pada anak dalam kondisi tertentu atau yang disebut dengan prinsip Kewarganegaraan ganda terbatas. Yang dimaksud dengan terbatas disini adalah bahwa terhadap anak-anak hasil kawin campur diberikan batas waktu terakhir sampai berusia 21 tahun untuk memilih salah satu kewarganegaraan yang dimiliki yaitu memilih antara berkewarganegaraan Indonesia atau berkewarganegaraan asing. (2) Wacana penerapan kewarganegaraan ganda memerlukan kajian, pandangan, dan masukan dari pakar. Kalaupun harus ada revisi terhadap Undang-Undang Nomor 12 tahun 2006 tentang Kewarganegaraan, Indonesia harus tetap menganut sistem kewarganegaraan tunggal, bukan kewarganegaraan ganda, karna kewarganegaraan ganda tidak memberikan kepastian hukum bagi masyarakat, disamping itu kewarganegaraan ganda juga lebih banyak berdampak negatifbagi bangsa dan Negara Indonesia
\end{abstract}

Kata Kunci : Kewarganegaraan Ganda

A. Pendahuluan

Masalah status kewarganegaraan merupakan masalah yang sangat penting jika dikaitkan dengan eksistensi suatu negara. ${ }^{1}$ Karena warga negara merupakan salah satu unsur dari negara yang harus dipenuhi untuk bisa disebut sebagai sebuah Negara. ${ }^{2}$ Di sisi lain status kewarganegaraan merupakan hak konstitusional setiap individu sebagaimana disebutkan dalam Pasal 28D ayat (4) UndangUndang Dasar Negara Republik Indonesia tahun 1945 yang menyebutkan bahwa "setiap orang berhak atas status kewarganegaraan".

Hal senada juga disebutkan didalam Pasal 15 ayat (1) dan ayat (2) Deklarasi Universal Hak Asasi Manusia (selanjutnya disingkat dengan DUHAM) menyebutkan bahwa "setiap orang berhak atas sesuatu kewarganegaraan, dan

${ }^{1}$ Hadidjojo dan Soejono, Kewarganegaraan Indonesia, Yogyakarta, Jajasan BP Gajah Mada, 1999, Hlm 39

2Lihat Pasal 1 Konvensi Montevideo 1993 
tidak seorang pun dengan semena-mena dapat dicabut kewarganegaraannya atau ditolak hanya untuk mengganti kewarganegaraannya". Dari ketentuan ini dapat dipahami bahwa dalam mendapatkan suatu kewarganegaraan telah menjadi hak dasar bagi setiap individu, termasuk bagi mereka yang berniat mengganti kewarganegaraan sebelumnya.

Tidak ada seorang pun atau sebuah organisasi manapun yang bisa semena-mena melakukan pencabutan atau pelarangan terhadap seseorang untuk memperoleh status kewarganegaraan tertentu. ${ }^{3}$ Prinsip yang umum dipakai untuk pengaturan kewarganegaraan sampai saat ini adalah prinsip "ius soli" yaitu prinsip yang mendasarkan diri pada pengertian hukum mengenai tanah kelahiran, dan prinsip "ius sanguinis" yaitu prinsip yang mendasarkan diri pada hubungan darah. $^{4}$

Berdasarkan prinsip "ius soli" seseorang yang dilahirkan di dalam wilayah hukum suatu negara, secara hukum dianggap memiliki status kewarganegaraan dari negara tempat kelahirannya itu. Prinsip ini salah satunya dianut oleh United State Of America (U.S.A) dan sebagian besar negara di Eropa. Sedangkan berdasarkan prinsip "ius sanguinis" seseorang yang mempunyai pertalian darah dengan orang tua dari negara tertentu, secara hukum dianggap sebagai warga Negara mengikuti kewarganegaraan orang tuanya meskipun ia lahir di negara lain. Salah satu negara yang menganut prinsip ini adalah Indonesia. ${ }^{5}$ Dalam era globalisasi seperti saat ini, kita menyaksikan banyak sekali penduduk suatu negara yang berpergian keluar negeri, baik karena direncanakan dengan sengaja ataupun tidak. Bahkan dapat pula terjadi, karena alasan untuk mempermudah urusan administrasi disuatu Negara tempat tujuan, seseorang sengaja untuk menetap bahkan menjadi warga Negara dimana tempat tujuannya tersebut, agar dapat diperlakukan sama dengan warga Negaranya sehingga dalam hal pengurusan apapun lebih mudah.

Dalam hal, negara tempat asal seseorang dengan Negara tempat ia menetap atau menjadi warga Negara menganut sistem kewarganegaraan yang sama, tentu tidak akan menimbulkan persoalan. Akan tetapi, apabila kedua negara yang bersangkutan memiliki sistem yang berbeda, maka dapat terjadi keadaan yang menyebabkan seseorang menyandang status kewarganegaraan ganda atau sebaliknya malah menjadi tidak berkewarganegaraan sama sekali (stateless). ${ }^{6}$

${ }^{3}$ Harsono, Hukum Tata Negara Perkembangan Pengarturan Kewarganegaraan, Yoyakarta, Liberty, 1992, hlm 3

${ }^{4}$ Ramly Hutabarat, Laporan Akhir Pengkajian Hukum Tentang Masalah Hukum Dwi Kewarganegaraan, Departemen Kehakiman dan HAM RI Badan Pembinaan Hukum Nasional, Jakarta, 2004, hlm 1

${ }^{5}$ Ibid. hlm 2

${ }^{6}$ Koerniatmanto Soetoprawiro, Hukum Kewarganegaraan dan Keimigrasian Indonesia. Jakarta. PT Gramedia Pustaka Utama, 1996, hlm 9 
Sebagaimana kasus yang terjadi pada Pengangkatan Archandra Tahar sebagai Menteri Negara Energi dan Sumber Daya Mineral pada akhir Juli 2016 menuai polemik. Dikarenakan Archandra Tahar diduga memiliki status kewarganegaraan ganda, yaitu Amerika Serikat dan Indonesia. Berdasarkan hal tersebut, Presiden Joko Widodo telah memberhentikan dengan hormat Archandra Tahar dari jabatan Menteri Negara Energi dan Sumber Daya Mineral pada tanggal 20 Agustus 2016. ${ }^{7}$ Selain Archandra Tahar, perkara status kewarganegaraan ganda juga menimpa Gloria N. Hamel yang berstatus kewarganegaraan ganda yakni Perancis dan Indonesia karena merupakan anak hasil pernikahan campuran dan masih berusia di bawah 18 tahun. Gloria pada awalnya tidak diperbolehkan bergabung sebagai anggota Pasukan Pengibar Bendera (Paskibra) pada hari kemerdekaan Indonesia 17 Agustus 2016 di Istana Negara. ${ }^{8}$

Permasalahan kewarganegaraan ganda Archandar Tahar dan Gloria N. Hamel mempunyai kemiripan, yaitu sama-sama memiliki 2 (dua) status kewarganegaraan. Berdasarkan Undang-Undang Nomor 12 tahun 2006 tentang Kewarganegaraan, Indonesia secara tegas tidak mengenal status kewarganegaraan ganda ataupun tanpa kewarganegaraan. Kewarganegaraan ganda yang diberikan kepada anak dalam Undang-Undang Nomor 12 tahun 2006 tentang Kewarganegaraan merupakan suatu pengecualian. Kewarganegaraan ganda hanya dimungkinkan sebagaimana diatur dalam Pasal 4 huruf c, d, h, dan 1 serta Pasal 5 ayat (1) dan ayat (2) Undang-Undang Nomor 12 tahun 2006 tentang Kewarganegaraan yang menyebutkan sebagai berikut: (1) Anak yang lahir dari perkawinan yang sah dari seorang ayah Warga Negara Indonesia dan ibu warga negara asing, (2) Anak yang lahir dari perkawinan yang sah dari seorang ayah warga negara asing dan ibu Warga Negara Indonesia, (3) Anak yang lahir di luar perkawinan yang sah dari seorang ibu warga negara asing yang diakui oleh seorang ayah Warga Negara Indonesia sebagai anaknya dan pengakuan itu dilakukan sebelum anak tersebut berusia 18 (delapan belas) tahun atau belum kawin, (4) Anak yang dilahirkan di luar wilayah negara Republik Indonesia dari seorang ayah dan ibu Warga Negara Indonesia yang karena ketentuan dari negara tempat anak tersebut dilahirkan memberikan kewarganegaraan kepada anak yang bersangkutanm, (5) Anak Warga Negara Indonesia yang lahir di luar perkawinan yang sah, belum berusia 18 (delapan belas) tahun dan belum kawin diakui secara sah oleh ayahnya yang berkewarganegaraan asing tetap diakui sebagai Warga Negara Indonesia, serta (6) Anak Warga Negara Indonesia yang belum berusia 5

${ }^{7}$ Harris Y. P. Sibuea, Wacana Penerapan Kewarganegaraan Ganda Di Indonesia, Majalah Info Singkat Hukum, Vol. VIII, No. 16/II/P3DI/Agustus/2016. Hlm 1

8Suryana, Indonesia Kewarganegaraan Ganda di akses di http://www.bbc.com/indonesia/berita_indonesia/2016/08/160817_indonesia_kewargane garaan_ganda tanggal 7 November 2016 
(lima) tahun diangkat secara sah sebagai anak oleh warga negara asing berdasarkan penetapan pengadilan tetap diakui sebagai Warga Negara Indonesia.

Kasus kewarganegaraan ganda yang menimpa mantan Menteri Energi dan Sumber Daya Mineral Archandra Tahar dan Anggota Paskibraka Gloria N. Hamel membuat Dewan Perwakilan Rakyat (DPR) mempertimbangkan untuk merevisi Undang-Undang Nomor 12 tahun 2006 tentang Kewarganegaraan. Rencana revisi atas Undang-Undang Nomor 12 tahun 2006 tentang Kewarganegaraan dituangkan dalam Program Legislasi Nasional 2014-2019 dengan pemrakarsa DPR yang akan memasukan kewarganegaraan ganda untuk diterapkan di Indonesia. Hal ini dilakukan untuk mengakomodasi talenta-talenta pemuda Indonesia yang berkewarganegaraan asing.

B. Pembahasan

1. Pengaturan kewarganegaraan ganda dalam Undang-Undang Nomor 12 tahun 2006 tentang Kewarganegaraan

Warga Negara atau kewarganegaraan merupakan salah satu unsur konstitutif keberadaan atau eksistensi suatu negara, warga negara merupakan salah satu hal yang bersifat prinsipal dalam kehidupan bernegara, tidak mungkin ada negara tanpa warga negara, begitu juga sebaliknya ${ }^{9}$. Kewarganegaraan menunjukkan hubungan hukum atau ikatan secara timbal balik antara negara dengan warga negara. Kewarganegaraan merupakan dasar yang sangat penting bagi negara untuk menentukan siapa warga negara dan orang asing.

Penentuan status kewarganegaraan dilakukan berdasarkan asas kewarganegaraan yang diterapkan dalam suatu Negara. Harus disadari bahwa setiap Negara memiliki kebebasan untuk menentukan asas kewarganegaraan ini terkait dengan penentuan persoalan kewarganegaraan seseorang. Asas kewarganegaraan merupakan pedoman dasar bagi suatu negara untuk menentukan siapakah yang menjadi warga negaranya ${ }^{10}$. Pasal 26 Undang-Undang Dasar Negara Republik Indonesia tahun 1945 (selanjutnya disingkat UUD NRI 1945) menyebutkan bahwa :

"(1)yang menjadi warga negara ialah orang-orang bangsa Indonesia asli dan orang-orang bangsa lain yang disahkan dengan undang-undang sebagai warga negara.

(2)Penduduk ialah warga negara Indonesia dan orang asing yang bertempat tinggal di Indonesia.

${ }^{9}$ Eka Martiana Wulansari, Konsep Kewarganegaran Ganda Tidak Terbatas (Dual Nasionality) Dalam Sistem Kewarganegaraan Di Indonesia, Jurnal RechtsVinding online, Media Pembinaan Hukum Nasional, 2010, hlm 1

${ }^{10}$ Koerniatmanto Soetoprawiro, Op.Cit. hlm 10 
(3)Hal-hal mengenai warga negara dan penduduk diatur dengan undangundang"

Kemudian diatur lebih lanjut dalam Pasal 2 Undang-Undang Nomor 12 Tahun 2006 tentang Kewarganegaraan yang menyebutkan bahwa:

"Yang menjadi Warga Negara Indonesia adalah orang-orang bangsa Indonesia asli dan orang-orang bangsa lain yang disahkan dengan undangundang sebagai warga Negara".

Berdasarkan ketentuan di atas menurut penulis bahwa pada dasarnya kewarganegaraan merupakan sebuah tanda (identitas) yang menunjukan adanya suatu ikatan berupa hubungan hukum antara seorang warga negara (individu) dengan negara. Hubungan hukum tersebut kemudian menimbulkan akibat hukum yang berupa munculnya hak dan kewajiban konstitusional warga negara.

Adapun yang dimaksud dengan hak konstitusional menurut (constitutional right) menurut Jimly Asshiddiqie adalah hak-hak yang dijamin di dalam dan oleh UUD 1945 (konstitusi). ${ }^{11}$ Siapapun dia jika diakui secara sah sebagai warga negara secara yuridis memiliki hak konstitusional (constututional right) yang dijamin dalam konstitusi sebuah negara.

Permohonan pewarganegaraan ini bisa diajukan oleh setiap orang asing yang ingin memperoleh status kewarganegaraan Indonesia kepada presiden melalui menteri selama yang bersangkutan telah memenuhi persyaratan tertentu yang ditentukan oleh Undang-undang. Adapun syarat-syarat yang harus dipenuhi untuk mengajukan permohonan pewarganegaraan sesuai dengan ketentuan Pasal 9 Undang-Undang Nomor 12 Tahun 2006 tentang kewarganegaraan yang menyebutkan bahwa:

1. Telah berusia 18 tahun atau sudah kawin.

2. Pada waktu mengajukan permohonan sudah bertempat tinggal di wilayah republik Indonesia paling singkat 5 tahun berturut-turut atau paling singkat 10 tahun tidak berturut-turut.

3. Sehat jasmani dan rohani.

4. Dapat berbahasa Indonesia serta mengakui dasar Negara pancasila dan UUD NRI tahun 1945.

5. Tidak pernah dijatuhi pidana karena melakukan tindak pidana yang diancam dengan pidana penjara 1 tahun atau lebih.

6. Jika dengan memperoleh kewarganegaraan Republik Indonesia, tidak menjadi berkewarganegaraan ganda.

7. Mempunyai pekerjaan dan penghasilan tetap.

11Jimly Asshiddiqie, Hak Konstitusional Di Indonesia, di akses di http://elsiusaragae.blogspot.com/2010/08/hak-konstitusional-di-indonesia.html, tanggal 20 Januari 2017 
8. Membayar uang pewarganegaraan ke kas Negara.

Lebih lanjut Pasal 2 sampai dengan Pasal 12 Peraturan Pemerintah Nomor 2 Tahun 2007 tentang tata cara memperoleh, kehilangan, pembatalan, dan memperoleh kembali kewarganegaraan Republik Indonesia menyebutkan bahwa proses pewarganegaraan dapat ditempuh dengan cara sebagai berikut:

a) Permohonan diajukan di Indonesia oleh pemohon secara tertulis dalam Bahasa Indonesia di atas kertas bermaterai cukup dan sekurangkurangnya memuat:

1. Nama lengkap

2. Tempat dan tanggal lahir

3. Jenis kelamin

4. Status perkawinan

5. Alamat tempat tinggal

6. Pekerjaan

7. Kewarganegaraan asal

Permohonan harus dilampiri dengan:

a. Fotokopi kutipan akte kelahiran atau surat yang membuktikan kelahiran pemohon yang disahkan oleh pejabat.

b. Fotokopi kutipan akte perkawinan/surat talak/perceraian, atau kutipan akte kematian istri/suami pemohon bagi yang berusia belum 18 (delapan belas) tahun yang disahkan oleh pejabat.

c. Surat keterangan keimigrasian yang dikeluarkan oleh kantor imigrasi yang wilayah kerjanya meliputi tempat tinggal pemohon yang menyatakan bahwa pemohon telah bertempat tingal di wilayah negara RI paling singkat 5 (lima) tahun berturut-turut atau paling singkat 10 (sepuluh) tahun tidak berturut-turut.

d. Fotokopi kartu izin tinggal tetap yang disahkan oleh pejabat.

e. Surat keterangan sehat jasmani dan rohani dari rumah sakit.

f. Surat pernyataan pemohon dapat berbahasa Indonesia.

g. Surat pernyataan pemohon mengakui dasar Negara pancasila dan UUD NRI Tahun 1945 .

h. Surat keterangan catatan kepolisian yang wilayah kerjanya meliputi tempat tinggal pemohon.

i. Surat keterangan dari perwakilan Negara pemohon bahwa dengan memperoleh kewarganegaraan Indonesia tidak menjadi berkewarganegaraan ganda.

j. Surat keterangan dari camat yang wilayah kerjanya meliputi tempat tinggal pemohon bahwa pemohon memiliki pekerjaan dan/atau berpenghasilan tetap. 
k. Bukti pembayaran uang pewarganegaraan dan biaya permohonan ke kas Negara.

1. Pas foto pemohon terbaru berwarna ukuran $4 \times 6$ (empat kali enam) sentimeter sebanyak 6 (enam) lembar.

b) Permohonan disampaikan kepada pejabat yang wilayah kerjanya meliputi tempat tinggal pemohon untuk dilakukan pemeriksaan kelengkapan persyaratan administratif permohonan beserta lampirannya.

c) Selanjutnya pejabat melakukan pemeriksaan substantif permohonan dalam waktu paling lama 14 (empat belas) hari terhitung sejak tanggal permohonan diterima. Dalam hal ini, aka nada 2 macam kondisi yang akan dihadapi oleh si pemohon. Permohonan akan dikembalikan kepada pemohon jika dianggap tidak memenuhi persyaratan substantif dalam waktu paling lama 7 (tujuh) hari terhitung sejak tanggal pemeriksaan substantif selesai dilakukan. Bila permohonan dinyatakan memenuhi persyaratan substantive maka akan diteruskan kepada menteri paling lama 7 (tujuh) hari terhitung sejak tanggal pemeriksaan substantif selesai dilakukan.

d) Setelah berkas diterima, maka menteri akan melakukan pemeriksaan substantive dan meneruskan permohonan yang disertai dengan pertimbangan kepada presiden dalam waktu paling lama 45 hari terhitung sejak tanggal permohonan diterima dari pejabat. Dan dalam hal jika diperlukan, menteri dapat meminta pertimbangan dari instansi terkait. Instansi terkait yang dimintai pertimbangan oleh menteri dapat memberikan pertimbangannya secara tertulis paling lambat 14 hari terhitung dari tanggal permintaan pertimbangan oleh menteri diterima. Jika dalam waktu yang dimaksud sebagaimana dalam pernyataan di atas, maka instansi terkait dianggap tidak berkeberatan.

e) Permohonan yang telah melalui pemeriksaan subtstantif yang diterima oleh presiden dari menteri juga akan mendapati 2 macam kondisi dikabulkan atau ditolak dalam waktu paling lambat 45 hari terhitung sejak tanggal permohonan diterima dari menteri. Jika permohonan dikabulkan, presiden menetapkan keputusan presiden dan memberitahukan secara tertulis kepada pemohon dengan tembusan kepada pejabat dalam waktu paling lambat 14 hari terhitung sejak tanggal keputusan presiden ditetapkan. Petikan dari keputusan presiden akan disampaikan kepada pejabat untuk diteruskan kepada pemohon dan salinannya disampaikan kepada menteri, pejabat, dan perwakilan negara asal pemohon.

f) Selanjutnya, pejabat memanggil pemohon secara tertulis untuk mengucapkan sumpah atau menyatakan janji setia dalam waktu paling lambat 3 bulan terhitung sejak tanggal pemberitahuan petikan keputusan 
presiden dikirim kepada pemohon. Pemohon memenuhi pemanggilan pengucapan sumpah atau mengucapkan janji setia dan dilakukan dihadapan pejabat dan disaksikan oleh 2 orang saksi. Jika pemohon tidak memenuhi pemanggilan dengan alasan yang sah, pengucapan sumpah atau pernyataan janji setia masih dapat dilakukan dihadapan pejabat selama masih dalam batas waktu (45 hari). Pengucapan sumpah atau pernyataan janji setia ini dibuatkan berita acaranya dalam 4 (empat) rangkap:

1. Rangkap pertama untuk pemohon.

2. Rangkap kedua untuk disampaikan kepada menteri.

3. Rangkap ketiga disampaikan kepada Menteri Sekretaris Negara.

4. Rangkap keempat disimpan oleh pejabat.

Berita acara pengucapan sumpah atau pernyataan janji setia rangkap pertama disampaikan kepada pemohon dalam waktu paling lambat 14 hari terhitung sejak tanggal pengucapan sumpah atau pernyataan janji setia. Jika selama dalam batas waktu yang ditentukan sebagaimana dinyatakan dalam Pasal 7 ayat 1 pemohon masih juga tidak memenuhi pemanggilan secara tertulis untuk mengucapkan sumpah atau menyatakan janji setia oleh pejabat dengan alasan yang sah, maka keputusan presiden batal demi hukum. Selanjutnya pejabat melaporkan keputusan presiden yang telah batal demi hukum tersebut kepada menteri dengan melampirkan petikan keputusan presiden yang bersangkutan.

g) Apabila dalam waktu 3 bulan sebagaimana dimaksud dalam pasal 7 ayat (1) pemohon tidak dapat mengucapkan sumpah atau menyatakan janji setia sebagai atau yang diakibatkan oleh kelalaian pejabat, pemohon dapat mengucapkan sumpah atau menyatakan janji setia dihadapan pejabat lain yang ditunjuk oleh menteri, (dilakukan selambat-lambatnya 14 hari terhitung sejak tanggal menerima laporan mengenai kelalaian pejabat sebelumnya). Pejabat lain yang telah ditunjuk harus memanggil pemohon untuk mengucapkan sumpah atau menyatakan janji setia selambat-lambatnya 14 hari sejak tanggal penunjukannya oleh menteri.

h) Selanjutnya, setelah melakukan pengucapan sumpah atau menyatakan janji setia, pemohon wajib mengembalikan dokumen atau surat-surat keimigrasian atas namanya ke kepada kantor imigrasi yang wilayah kerjanya meliputi tempat tinggal pemohon dalam waktu paling lambat 14 hari terhitung sejak tanggal pengucapan sumpah atau pernyataan janji setia. Jika dalam hal ini pemohon memiliki anak yg dibawah usia 18 tahun atau belum kawin, maka akan ikut memperoleh kewarganegaraan 
pemohon, dan pemohon juga harus mengembalikan dokumen atau suratsurat keimigrasian atas nama anak ke kantor imigrasi yang sama.

i) Jika permohonan sebagaimana yang dimaksud dalam pasal 6 ayat (1) dinyatakan di tolak, maka presiden akan memberitahukan kepada menteri. Permohonan yang ditolak akan diberitahukan secara tertulis oleh menteri kepada pemohon disertai dengan alasan lewat tembusan kepada pejabat dalam waktu paling lambat 3 bulan terhitung sejak tanggal permohona diterima oleh menteri.

j) Selanjutnya, bagi pemohon yang disetujui dan telah memperoleh kewarganegaraan RI akan diumumkan oleh menteri dalam Berita Negara Republik Indonesia. Pengumuman dilakukan setelah berita acara pengucapan sumpah atau pernyataan janji setia diterima oleh menteri.

k) Dengan ini pemohon resmi berkewarganegaraan Indonesia.

Berdasarkan Undang-Undang Nomor 12 tahun 2006 tentang Kewarganegaraan, Indonesia secara tegas tidak menerapkan status kewarganegaraan ganda, kecuali pada anak dalam kondisi tertentu atau yang disebut dengan prinsip Kewarganegaraan ganda terbatas. Yang dimaksud dengan terbatas disini adalah bahwa terhadap anak-anak hasil kawin campur diberikan batas waktu terakhir sampai berusia 21 tahun untuk memilih salah satu kewarganegaraan yang dimiliki yaitu memilih antara berkewarganegaraan Indonesia atau berkewarganegaraan asing dan hal ini harus dinyatakan. ${ }^{12}$

Pada dasarnya Indonesia menganut asas atau prinsip kewarganegaraan tunggal (single nasionality). Prinsip ini telah dianut sejak Proklamasi 17 Agustus Tahun 1945 dengan menerbitkan Undang-Undang Nomor 62 Tahun 1958 tentang Kewarganegaraan, dan terakhir di perbaharui dengan Undang-Undang Nomor 12 Tahun 2006 tentang Kewarganegaraan.

Lahirnya Undang-Undang Nomor 12 tahun 2006 tentang kewarganegaraan merupakan suatu lombatan besar dari undang-undang sebelumnya yakni UndangUndang Nomor 62 tahun 1958. Meskipun pada prinsipnya adalah sama yaitu kewarganegaraan tunggal, tetapi dalam undang-undang ini diperkenalkanlah prinsip kewarganegaraan ganda terbatas. Undang-undang ini juga memperlihatkan adanya penerapan dua asas penentuan status kewarganegaraan sebagaimana terlihat dalam ketentuan Pasal 4 Undang-Undang Nomor 12 tahun 2006 tentang Kewarganegaraan dimana mereka yang belum berusia 18 tahun atau belum menikah dan setelah anak tersebut berusia 21 tahun, maka anak tersebut dapat memilih kewarganegaraannya sesuai kehendaknya.

Aturan tersebut terlihat secara jelas diterapkannya konsep kewarganegaraa ganda hanya saja terbatas sebagaimana yang telah penulis uraikan di atas.

12 Eka Martiana Wulansari, Op.Cit. hlm 5 
Penerapan status kewarganegaraan ganda terbatas yang dianur dalam UndangUndang Nomor 12 tahun 2006 tentang Kewarganegaraan dapat disebut sebagai sebuah terobosan untuk mengatasi problematika yang timbul dalam perkawinan campuran, maupun setelah putusnya perkawinan campuran, dimana terdapat perbedaan kewarganegaraan orangtua dan anak-anak hasil perwakinan itu yang kerap membuat sang anak terlindungi hak-haknya.

Terkait dengan persoalan kewarganegaraan ganda ini terdapat suatu kasus menarik terkait dengan persoalan kewarganegaran ganda ini yakni kasus Gloria N. Hamel yang berstatus kewarganegaraan ganda yakni Perancis dan Indonesia karena merupakan anak hasil pernikahan campuran dan masih berusia di bawah 18 tahun. Gloria pada awalnya tidak diperbolehkan bergabung sebagai anggota Pasukan Pengibar Bendera (Paskibra) pada hari kemerdekaan Indonesia 17 Agustus 2016 di Istana Negara. ${ }^{13}$

Menurut penulis bahwa kasus Pencoretan Gloria dari peserta Paskibraka adalah bentuk pelemahan spirit nasionalisme yang sudah tertanam di hati Gloria serta anak-anak Indonesia yang dilahirkan dari perkawinan campuran. Meskipun negara Indonesia menganut Kewarganegaraan tunggal, namun Undang-Undang Nomor 12 tahun 2006 tentang Kewarganegaraan kita juga mengatur dwi kewarganegaraan secara terbatas, khususnya untuk anak usia dibawah 18 tahun dan belum menikah.

Hal ini terlihat dari beberapa pasal yang mengatur tentang kewarganegaraan ganda terbatas sebagai berikut :

1. Pasal 4 huruf c, anak yang lahir dari perkawinan yang sah dari seorang ayah Warga Negara Indonesia dan ibu warga negara asing;

2. Pasal 4 huruf $d$, anak yang lahir dari perkawinan yang sah dari seorang ayah warga negara asing dan ibu Warga Negara Indonesia;

3. Pasal 4 huruf h,anak yang lahir di luar perkawinan yang sah dari seorang ibu warga negara asing yang diakui oleh seorang ayahWarga Negara Indonesia sebagai anaknya dan pengakuanitu dilakukan sebelum anak tersebut berusia 18 (delapanbelas) tahun atau belum kawin;

4. Pasal 4 huruf 1 , anak yang dilahirkan di luar wilayah negara Republik Indonesia dari seorang ayah dan ibu Warga NegaraIndonesia yang karena ketentuan dari negara tempat anaktersebut dilahirkan memberikan kewarganegaraan kepada anak yang bersangkutan

5. Pasal 5 ayat (1) ,Anak Warga Negara Indonesia yang lahir di luar perkawinan yang sah, belum berusia 18 (delapan belas)tahun dan belum

\footnotetext{
13Suryana, Indonesia Kewarganegaraan Ganda di akses di http://www.bbc.com/indonesia/berita_indonesia/2016/08/160817_indonesia_kewargane garaan_ganda tanggal 7 November 2016
} 
kawin diakui secara sah oleh ayahnyayang berkewarganegaraan asing tetap diakui sebagai Warga Negara Indonesia.

6. Pasal 5 ayat (2) ,Anak Warga Negara Indonesia yang belum berusia 5(lima) tahun diangkat secara sah sebagai anak oleh warganegara asing berdasarkan penetapan pengadilan tetapdiakui sebagai Warga Negara Indonesia.

7. Pasal 6 ayat (1) ,Dalam hal status Kewarganegaraan Republik Indonesia terhadap anak sebagaimana dimaksud dalam Pasal 4huruf c, huruf d, huruf h, huruf 1, dan Pasal 5 berakibatanak berkewarganegaraan ganda, setelah berusia 18 (delapan belas) tahun atau sudah kawin anak tersebut harus menyatakan memilih salah satu kewarganegaraannya.

Dari pasal-pasal diatas terlihat bahwa pada dasarnya, Undang-Undang Nomor. 12 tahun 2006 hanya memberlakukan kewarganegaraan ganda yang sifatnya terbatas. harusnya Menteri Sekretaris Negara dapat membaca secara teliti Undang-Undang Kewarganegaraan, dan paskibraka bukanlah pejabat negara. Dan ini berbanding terbalik dengan kasus mantan menteri Energi dan Sumber Daya Mineral Archandra Tahar yang menyangkut status kewarganegaraan dan pengangkatannya sebagai Menteri atau pejabat negara yang juga diatur oleh mekanisme perundang-undangan.

Pada awalnya yang bersangkutan berstatus Warga Negara Indonesia yang kemudian pindah untuk bekerja di Amerika Serikat. Dalam hal kepemilikan paspor negara Amerika Serikat, yang bersangkutan dapat dikatakan kehilangan kewarganegaraan Indonesia karena berdasarkan Pasal 23 huruf h Undang-Undang Nomor 12 tahun 2006 tentang Kewarganegaraan yang menyebutkan bahwa, "Warga Negara Indonesia kehilangan kewarganegaraannya jika yang bersangkutan mempunyai paspor atau surat yang bersifat paspor dari negara asing atau surat yang dapat diartikan sebagai tanda kewarganegaraan yang masih berlaku dari negara lain atas namanya".

Orang yang kehilangan kewarganegaraan Indonesia dapat memperoleh kembali kewarganegaraannya sebagaimana diatur dalam Pasal 31 Undang-Undang Nomor 12 tahun 2006 tentang Kewarganegaraan menyebutkan bahwa

"Seseorang yang kehilangan Kewarganegaraan Republik Indonesia dapat memperoleh kembali kewarganegaraannya melalui prosedur pewarganegaraan sebagaimana dimaksud dalam Pasal 9 sampai dengan Pasal 18 dan Pasal 22".

Permasalahannya, untuk mendapatkan kembali kewarganegaraan Indonesia yang hilang hanya dapat dilakukan melalui permohonan. Artinya semua persyaratan termasuk jangka waktu bertempat tinggal di Indonesia juga harus dipenuhi. Berbeda dengan pewarganegaraan bagi orang asing yang belum pernah menjadi WNI yang dimungkinkan melalui dua cara, yaitu berdasarkan 
permohonan (Pasal 9) dan naturalisasi (Pasal 20) Undang-Undang Nomor 12 tahun 2006 tentang Kewarganegaraan.

Pasal 20 Undang-Undang Nomor 12 tahun 2006 tentang Kewarganegaraan menyebutkan orang asing yang telah berjasa kepada negara Republik Indonesia atau dengan alasan kepentingan negara dapat diberi Kewarganegaraan Republik Indonesia oleh Presiden setelah memperoleh pertimbangan Dewan Perwakilan Rakyat Republik Indonesia, kecuali dengan pemberian kewarganegaraan tersebut mengakibatkan yang bersangkutan berkewarganegaraan ganda.

Dengan demikian solusinya bukan dengan menerapkan kewarganegaraan ganda, melainkan pemberian kewarganegaraan kembali oleh negara tanpa harus mengajukan permohonan. Hal ini yang belum diatur oleh Undang-Undang Nomor 12 tahun 2006 tentang Kewarganegaraan

2. Implikasi hukum terhadap penerapan kewarganegaraan ganda di Indonesia

Perkembangan globalisasi ekonomi dan hubungan internasional yang sangat pesat dewasa ini telah mengakibatkan kemudahan terhadap arus perputaran antara warganegara suatu negara menuju negara lain dengan alasan politik, ekonomi, dan sebagainya. Mereka saling berinteraksi satu sama lain sebagai penduduk suatu negara, bahkan ada yang mengikatkan diri dalam suatu perkawinan hingga akhirnya menetap.

Berkaitan dengan fenomena tersebut, maka jaminan status kewarganegaraan sangat diperlukan untuk mengukuhkan eksistensi suatu Negara maupun warganegara itu sendiri. Salah satu aspek dari jaminan legalitas status kewarganegaraan tersebut adalah masalah pewarganegaraan bagi warganegara asing yang berdomisili di suatu Negara tertentu dan berkeinginan untuk mengganti kewarganegaraannya.

Menjadi tidak bermasalah apabila perpindahan dengan maksud menetap yang diikuti dengan perpindahan kewarganegaraan hanya menimbulkan akibat hilangnya salah satu kewarganegaraan. Akan tetapi fenomena yang muncul adalah adanya tuntutan pemberlakukan kewarganegaraan ganda. Tuntutan ini menimbulkan pertanyaan mengenai loyalitas dan kesetiaan (loyalty and allegiance) yang biasanya melekat pada konsep kewarganegaraan. ${ }^{14}$ Menyikapi hal tersebut, Dewan Perwakilan Rakyat (DPR) mulai melakukan kajian-kajian dwi kewarganegaraan/kewarganegaraan ganda dari berbagai perspektif, seperti Hukum Tata Negara, Hukum Kewarganegaraan dan Keimigrasian, serta Hukum Internasional.

14 Susi Dwi Harijanti, Dwi Kewarganegaraan dan Politik Hukum Kewarganegaraan Indonesia, Disampaikan dalam acara Diskusi Penyusunan Konsep Naskah Akademik dan RUU tentang Kewarganegaraan Ganda, diselenggarakan oleh Sekretariat Jenderal DPR, Jakarta, 23 Oktober 2014. Hlm 3 
Kewarganegaraan ganda dalam konteks globalisasi, di satu sisi dapat dipandang sebagai "internal globalization" (globalisasi internal) dimana aturanaturan negara bangsa merespon ikatan-ikatan berbagai warga negara lintas batas negara, di sisi lain, kewarganegaraan ganda juga dapat dipandang sebagai "an incident of globalization" (kecelakaan dari globalisasi), mengingat berbagai persoalan yang berujung pada klaim atas kewarganegaraan ganda akibat migrasi internasional yang begitu masif dan tak terhindarkan sehingga berujung pada persoalan hukum. ${ }^{15}$

Tuntutan kewarganegaraan ganda perlu direspon dengan cermat. Tuntutan ini perlu dimaknai bahwa komunitas migran atau Indonesia telah membuka diri kepada "bangsa-nya" (Indonesia), untuk menjaring kembali dan memberdayakan berbagai potensi sumber daya manusia (SDM) Indonesia yang "berpindah" ke negara lain. Karena persoalan keterbatasan kemampuan internal Indonesia dalam memberdayakan SDM potensial di dalam negeri, sebagian WNI menetap di luar negeri demi mendapatkan penghidupan dan apresiasi yang lebih baik atas kemampuannya. Padahal mereka tidak pernah merasa melepas ikatan kebangsaannya dengan Indonesia, walaupun menetap di luar negeri atau bahkan telah berganti kewarganegaraan.

Negara asal perlu mengupayakan berbagai tindakan aktif untuk menjaring potensi WNI yang berada diluar negeri demi kepentingan negara dan masyarakatnya. Artinya, tanpa upaya serius untuk memaintaince hubungan dengan WNI diluar negeri, termasuk dengan negara tempat tinggalnya, negara asal sangat mungkin tidak mendapatkan apa-apa, kecuali berharap semua WNI diluar negeri berkontribusi secara sukarela bagi negara.

Namun demikian, Kewarganegaraan Ganda memudahkan para WNI yang ada di luar negeri untuk memelihara hubungan-hubungan dengan negara asalnya, dari berbagai hubungan yang bersifat rasional, seperti transfer ilmu pengetahuan, investasi di bidang sektor-sektor potensial, hingga hubungan - hubungan yang bersifat emosional dengan keluarga dan masyarakat asalnya.

Secara umum, pengaturan kewarganegaraan ganda dalam hukum kewarganegaraan Indonesia menjadi penting untuk diakomodasi. Bahkan dari perspektif hak asasi manusia dalam hukum nasional, kewarganegaraan ganda di Indonesia mendapatkan ruang pengaturan yang lebih luas, mengingat jaminan hak atas kewarganegaraan dalam UUD NRI 1945, tidak dibatasi pada klaim atas "satu kewarganegaraan", namun hak untuk memilih kewarganegaraan. Artinya, pilihan satu atau dua kewarganegaraan, sangat berkaitan politik hukum nasional kita untuk merespon globalisasi, melindungi hak asasi manusia, termasuk mengantisipasi implikasi dari migrasi internasional, sekaligus memberdayakan sumber daya manusia Indonesia di luar negeri untuk kepentingan nasional.

15 Ibid. hlm 6 
Munculnya tuntutan untuk diterapkannya kewarganegaraan ganda menjadi pertimbangan bagi Pemerintah dan DPR RI untuk melakukan perubahan terhadap Undang-Undang Nomor 12 tahun 2006 tentang Kewarganegaraan yang menjadi tuntutan dari masyarkat yang berada diluar negeri untuk diterapkannya kewarganegaraan ganda (dual nasionality) ke dalam perubahan Undang-Undang Nomor 12 Tahun 2006 tentang Kewarganegaraan Republik Indonesia.

Walaupun tuntutan terhadap kewarganegaraan ganda mulai meluas, namun sebagian negara selalu mengkaitkan pengakuan tersebut berdasarkan "ikatan khusus" terhadap negaranya. Artinya, pengakuan kewarganegaraan ganda sangat dimungkinkan untuk diberikan dengan kualifikasi tertentu. Kualifikasi yang dimaksud terkait dengan kriteria subjek yang diakui memiliki kewarganegaraan Indonesia dan secara simultan memiliki kewarganegaraan asing. oleh karena asas kewarganegaraan yang menjadi dasar hukum kewarganegaraan Indonesia adalah ius sangunis, maka pengakuan kewarganegaraan ganda harus didasarkan pada asas tersebut. Artinya, kewarganegaraan ganda hanya dimungkinkan bagi orang yang kewarganegaraan asalnya (sejak kelahiran) adalah Indonesia (original acquisition), dan kemudian mendapatkan status kewarganegaraan asing di kemudian hari, termasuk bagi keturunannya (generasi kedua) yang sebelumnya telah dijamin oleh Undang-Undang Nomor 12 tahun 2006 tentang Kewarganegaraan.

Dengan demikian, status Kewarganegaraan ganda dikecualikan bagi orang asing yang mendapatkan status WNI melalui perolehan kewarganegaraan secara derivatif (derivative acquisition), seperti naturalisasi atau karena perkawinan campuran. Penerapan kewarganegaraan ganda memiliki keungtungan dan kerugian diantaranya yaitu

a. Keuntungan Kewarganegaraan Ganda

1. Meningkatkan perekonomian yaitu: PDB naik, kemudahan transaksi, investasi, bisnis dan mendorong pembangunan dan pengembangan.

2. Meningkatkan daya saing dan penerimaan Negara

3. Menciptakan lapangan kerja baru

4. Jembatan untuk infestasi, negosiasi, alih teknologi dan pembangunan infrastuktur

5. Mendorong peningkatan hubungan kerja sama antar Negara (Ekonomi, sosial, Hukum) Memudahkan family reunion, sirkulasi asset dan pertukaran budaya (bahasa, aktifitas budaya, ide)

6. Memudahkan family reunion, sirkulasi asset dan pertukaran budaya (bahasa, aktifitas budaya, ide)

7. Meningkatkan potensi SDM, alih kompetensi dan keterampilan sehingga mengurangi ketergantungan terhadap asing

8. Menjaga stabilitas kawasan atau perdamaian internasional. 
b. Kerugian Kewarganegaraan Ganda

1. Menimbulkan Kewajiban Ganda (pajak dan Military Service)

2. Masih bisa mendapatkan prilaku yang berbeda (Hak politik dan Sosial)

3. Kebingungan dalam mengimplementasikan Hak dan Kewajiban sebagai seorang warga Negara

4. Rendahnya partisipasi social bagi kedua Negara

5. Mendorong keluarga atau kerabat untuk pindah/migrasi

6. Penurunan loyalitas terhadap bangsa dan Negara

7. Memungkinkanya tindakan illegal atau menghindari hukum ${ }^{16}$

Hikmahanto J uwana, pakar hukum internasional Universitas Indonesia, menyatakan bahwa ada beberapa hal yang harus dipertimbangkan jika Indonesia ingin menerapkan kewarganegaraan ganda. Salah satunya kewarganegaraan ganda seringkali dimanfaatkan oleh seseorang yang melakukan kejahatan dan penghindaran pajak. $^{17}$

Jika wacana perubahan Undang-Undang Nomor 12 tahun 2006 tentang Kewarganegaraan yang di dalamnya akan mengakui status kewarganegaraan ganda sebagai respons dari peristiwa yang menimpa Archandra Tahar dan Gloria $\mathrm{N}$. Hamel adalah tindakan terburu-buru yang tidak melewati proses pengkajian terlebih dahulu. Wacana penerapan kewarganegaraan ganda memerlukan kajian,pandangan, dan masukan dari pakar. Kalaupun harus ada revisi, Indonesia harus tetap menganut sistem kewarganegaraan tunggal, bukan kewarganegaraan ganda. Meski hukum harus mengikuti perkembangan dunia karena dunia sudah berubah, dengan memberikan hak- hak sosial, ekonomi, dan hak asasi manusia, kecuali hak politik.

Opsi tidak mengakomodir wacana kewarganegaraan ganda dalam peraturan perundang-undangan lebih memberikan kepastian hukum dalam status kewarganegaraan di Indonesia. Walaupun hukum selalu merespons permasalahan sosial yang terjadi dalam masyarakat, khususnya terhadap kasus kewarganegaraan ganda Archandra Tahar dan Gloria N. Hamel yang baru saja terjadi, namun bukan berarti hukum langsung mengakomodir permasalahan tersebut ke dalam peraturan perundang-undangan.

C. Penutup

\section{Kesimpulan}

Berdasarkan uraian diatas, maka penulis dapat menarik kesimpulan sebagai berikut :

1. Indonesia secara tegas tidak menerapkan status kewarganegaraan ganda di dalam Undang-Undang Nomor 12 tahun 2006 tentang Kewarganegaraan, kecuali pada anak dalam kondisi tertentu atau yang disebut dengan prinsip Kewarganegaraan

16 Eka Martiana Wulansari, Op.Cit. hlm 9

17 Eka Martiana Wulansari, Op.Cit. hlm 4 
ganda terbatas. Yang dimaksud dengan terbatas disini adalah bahwa terhadap anak-anak hasil kawin campur diberikan batas waktu terakhir sampai berusia 21 tahun untuk memilih salah satu kewarganegaraan yang dimiliki yaitu memilih antara berkewarganegaraan Indonesia atau berkewarganegara an asing.

2. Wacana penerapan kewarganegaraan ganda memerlukan kajian, pandangan, dan masukan dari pakar. Kalaupun harus ada revisi terhadap Undang-Undang Nomor 12 tahun 2006 tentang Kewarganegaraan, Indonesia harus tetap menganut sistem kewarganegaraan tunggal, bukan kewarganegaraan ganda, karna kewarganegaraan ganda tidak memberikan kepastian hukum bagi masyarakat, disamping itu kewarganegaraan ganda juga lebih banyak berdampak negatif bagi bangsa dan Negara Indonesia

2. Saran

Adapun saran yang dapat penulis sampaikan yakni sebagai berikut :

1. Perlu adanya pengaturan yang lengkap didalam Undang-Undang Nomor 12 tahun 2006 tentang Kewarganegaraan yang sesuai dengan perkembangan zaman di era globlalisasi seperti sekarang ini tanpa harus merugikan kepentingan Negara Republik Indonesia

2. Sebaiknya pemerintah mengkaji secara mendalam terkait wacana revisi Undang-Undang Nomor 12 tahun 2006 tentang Kewarganegaraan yang mengakomodir kewarganegaraan ganda karena kewarganegaraan ganda tidak memberikan kepastian hukum kepada warga negara

Daftar Pustaka

A. Buku-Buku

Eka Martiana Wulansari, Konsep Kewarganegaran Ganda Tidak Terbatas (Dual Nasionality) Dalam Sistem Kewarganegaraan Di Indonesia, Jurnal RechtsVinding online, Media Pembinaan Hukum Nasional, 2010

Hadidjojo dan Soejono, Kewarganegaraan Indonesia, Yogyakarta, Jajasan BP Gajah Mada, 1999.

Harsono, Hukum Tata Negara Perkembangan Pengarturan Kewarganegaraan, Yoyakarta, Liberty, 1992

Harris Y. P. Sibuea, Wacana Penerapan Kewarganegaraan Ganda Di Indonesia, Majalah Info Singkat Hukum, Vol. VIII, No. 16/II/P3DI/Agustus/2016

Koerniatmanto Soetoprawiro, Hukum Kewarganegaraan dan Keimigrasian Indonesia. Jakarta. PT Gramedia Pustaka Utama, 1996

Ramly Hutabarat, Laporan Akhir Pengkajian Hukum Tentang Masalah Hukum Dwi Kewarganegaraan, Departemen Kehakiman dan HAM RI Badan Pembinaan Hukum Nasional, Jakarta, 2004

Susi Dwi Harijanti, Dwi Kewarganegaraan dan Politik Hukum Kewarganegaraan Indonesia, Disampaikan dalam acara Diskusi Penyusunan Konsep 
Naskah Akademik dan RUU tentang Kewarganegaraan Ganda, diselenggarakan oleh Sekretariat Jenderal DPR, Jakarta, 23 Oktober 2014

Situs Internet

Suryana, Indonesia Kewarganegaraan Ganda di akses di http://www.bbc.com/indonesia/berita_indonesia/2016/08/160817_indonesia_ kewarganegaraan_ganda tanggal 7 November 2016

Jimly Asshiddiqie, Hak Konstitusional Di Indonesia, di akses di http://elsiusaragae.blogspot.com/2010/08/hak-konstitusional-diindonesia.html, tanggal 20 Januari 2017

Suryana, Indonesia Kewarganegaraan Ganda di akses di http://www.bbc.com/indonesia/berita_indonesia/2016/08/160817_indonesia_ kewarganegaraan_ganda tanggal 7 November 2016 